\title{
Specific leaf area and leaf area index in developing stands of Fagus sylvatica $L$. and Picea abies Karst
}

Article

Accepted Version

Konopka, B., Pajtik, J., Marusak, R., Bosela, M. and Lukac, M. (2016) Specific leaf area and leaf area index in developing stands of Fagus sylvatica L. and Picea abies Karst. Forest Ecology and Management, 364. pp. 52-59. ISSN 0378-1127 doi: https://doi.org/10.1016/j.foreco.2015.12.005 Available at https://centaur.reading.ac.uk/48686/

It is advisable to refer to the publisher's version if you intend to cite from the work. See Guidance on citing.

To link to this article DOI: http://dx.doi.org/10.1016/j.foreco.2015.12.005

Publisher: Elsevier

All outputs in CentAUR are protected by Intellectual Property Rights law, including copyright law. Copyright and IPR is retained by the creators or other copyright holders. Terms and conditions for use of this material are defined in the End User Agreement.

www.reading.ac.uk/centaur 
Central Archive at the University of Reading

Reading's research outputs online 


\section{Specific leaf area and leaf area index in developing stands of Fagus}

\section{2 sylvatica L. and Picea abies Karst.}

3

4 5

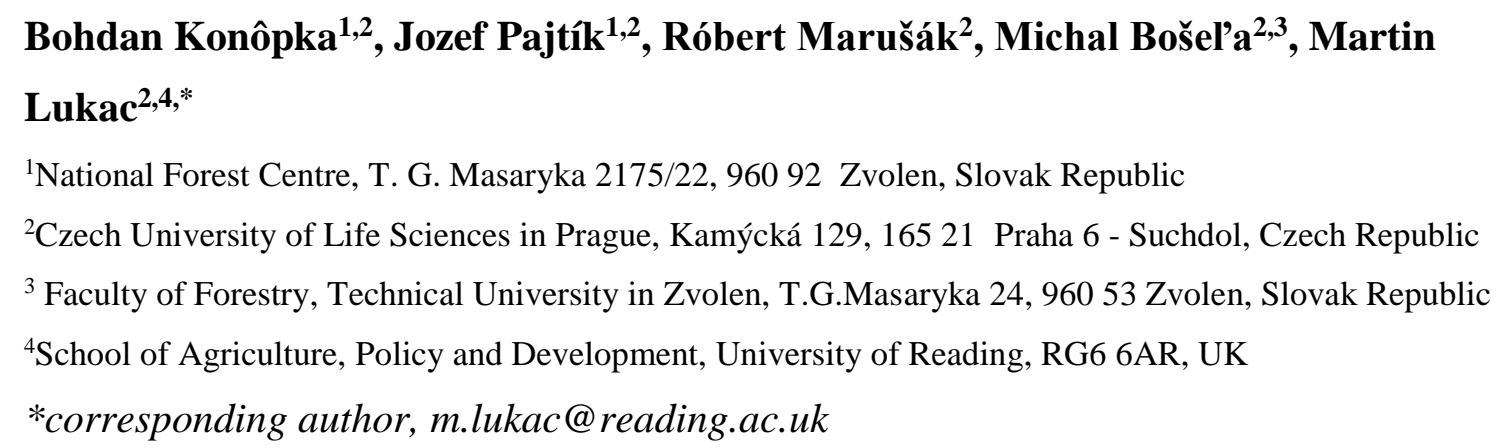

Keywords: beech, spruce, foliage, leaf mass, leaf area, growth efficiency, shading, canopy structure

\section{Abstract}

European beech (Fagus sylvatica L.) and Norway spruce (Picea abies Karst.) are two of the most ecologically and economically important forest tree species in Europe. These two species co-occur in many locations in Europe, leading to direct competition for canopy space. Foliage characteristics of two naturally regenerated pure stands of beech and spruce with fully closed canopies were contrasted to assess the dynamic relationship between foliage adaptability to shading, stand LAI and tree growth. We found that individual leaf size is far more conservative in spruce than in beech. Individual leaf and needle area was larger at the top than at the bottom of the canopy in both species. Inverse relationship was found for specific leaf area (SLA), highest SLA values were found at lowest light availability under the canopy. There was no difference in leaf area index (LAI) between the two stands, however LAI increased from 10.8 to $14.6 \mathrm{~m}^{2} \mathrm{~m}^{-2}$ between 2009 and 2011. Dominant trees of both species were more efficient in converting foliage mass or area to produce stem biomass, although this relationship changed with age and was species-specific. Overall, we found larger foliage plasticity in beech than in spruce in relation to light conditions, indicating larger capacity to exploit niche openings. 
Competition for light and resulting mortality are the most critical processes driving development of young forest stands (King, 1990). As the canopy closes, in particular in stands originating from natural regeneration, tree height relative to neighbours, but also position within a crown dictate light availability to foliage (Niinemets et al., 2001; Richardson et al., 2001). Leaves and needles are the only tissues with the capacity to capture energy and thus drive forest growth. Foliage responds very sensitively to growth conditions within a stand and has been shown to adapt its morphology (Bussotti et al., 2000), structure (Kull et al., 1999) and metabolism (Hallik et al., 2009) in response to light intensity.

Vertical distribution of foliage, but also changes in the size of individual leaves, have both been attributed to relative light conditions within the stand (Johansson, 1996). The relationship between light availability and specific leaf area (SLA, defined as leaf area per unit leaf mass) varies among tree species (Niinemets, 2010). No consensus currently exists as to whether different tree species exhibit greater leaf size plasticity in relation to light availability. Several studies report larger plasticity of leaf morphology in shade-intolerant than in shade-tolerant species (Oguchi et al., 2005; Sanchez-Gomez et al., 2006; Portsmuth and Niinemets, 2007), while others found the reverse (Paz, 2003; Delagrange et al., 2004) or no variation (Paquette et al., 2007). In addition to shade tolerance, SLA in trees is also influenced by tree age and size (Steele et al., 1990; Niinements and Kull, 1995). It is important to point out that tree age, size and irradiation gradient along the canopy are strongly correlated. Older and taller trees are likely to generate deeper canopies, which expose foliage to irradiation levels ranging from full to a fraction of full sunlight (Niinemets, 2010). 
Efficient light capture is of crucial importance to trees growing in dense stands with high level of competition for light (Pearcy et al., 2005). Trees maximise capture of available light by developing layered canopies with several strata of overlapping leaves. Defined as the total one-sided foliage area per unit ground area, Leaf Area Index (LAI) controls light interception, but also acts as a determinant of carbon and water exchange between forest canopy and the atmosphere (Leuschner et al., 2006), primary production (Long and Smith, 1990) and rainfall interception (Herbert and Fownes, 1999). Whilst the definition and measurement of leaf area is fairly straightforward in broadleaves, three different definitions have been proposed for conifers: total needle surface area, half of the total needle surface area, and projected needle area. The latter definition was used in this paper as it is commonly accepted as the most practical, but also indicative of the needle surface involved in light interception at any one time but also by stem density (Leuschner et al., 2006). of radiative energy to biomass, little is known about the mechanisms linking light interception and biomass allocation in trees. Description of foliage mass and foliage area, together with data on mass of wood compartments may allow for an investigation of growth efficiency of foliage. Several authors (e.g. (Pickup et al., 2005; Shipley, 2006; Milla et al., 2008) used the ratio total plant dry mass (leaf area ratio - LAR) to describe ecological and production interactions. However, none of these studies allow for the description of the dynamic relationship between 
described growth efficiency in temperate trees, albeit only on the basis of biomass partitioning and did not describe foliage dynamics.

Allometric relations are frequently used to assess biomass partitioning to various pools in forests (Claesson et al., 2001; Wirth et al., 2004; Fehrmann and Kleinn, 2006; Cienciala et al., 2008; Pajtík et al., 2011). In general, biomass contained in a particular tree compartment can be predicted by an allometric equation usually using tree height or diameter (at breast height, i.e. $\mathrm{DBH}$ ) as predictor variables (West et al., 2009). Estimates of foliage biomass in young beech and spruce stands were put forward by Kantor et al. (2009), whilst Xiao and Ceulemans (2004) established allometric equations for foliage at both branch and tree levels in young Scots pine. The latter study attempted to consider the vertical position of a whorl as one of the independent variables predicting foliage biomass. Having said that, biomass allometric equations by definition predict only foliage mass and do not offer any information about foliage area. Since leaf area and its stratification is key determinant of forest stand productivity, this paper aims to link allometric relations to foliage area and stand LAI.

Developing stands of pure Fagus sylvatica L. (beech) and pure Picea abies Karst. (spruce) with fully closed canopy are contrasted and their growth performance compared.

In particular, this paper links up information on foliage mass and foliage area for two of the most important European forest tree species growing on the same site. There are several levels at which these two species can be contrasted. As a deciduous tree, beech produced all of its foliage in current year, spruce on the other hand retains its needles for up to 5 years, possibly leading to higher LAI in spruce. Beech is shade-tolerant, while spruce is classified as intermediate in relation to its shade tolerance (Ellenberg and Leuschner, 1996). Lastly, since the selected site is located at the lower elevation limit of spruce in this area of Europe, climate 
change is expected to favour beech leading to eventual replacement of spruce by beech at this

106 elevation. Thus this study offers insights into effects of climatic warming on growth performance of forests currently occupying the climatic boundary between the two species.

108 In this study, we hypothesised that (i) spruce has higher LAI than beech, (ii) dominant trees of 109 both species have higher leaf mass ratio.

\section{Materials and methods}

\section{Site description}

113 The experimental site was located in the southern part of Slovak Ore Mountains, $977 \mathrm{~m}$ above 114 sea level $\left(48^{\circ} 38^{\prime} 50^{\prime \prime} \mathrm{N}\right.$ and $\left.19^{\circ} 36^{\prime} 12^{\prime \prime} \mathrm{E}\right)$. Annual sum of precipitation is close to $900 \mathrm{~mm}$, 115 while mean temperature is $5.2{ }^{\circ} \mathrm{C}$. The soil type has been classified as Humic Cambisol on 116 granodiorit bedrock, with a high stone content and $\mathrm{pH}\left(\mathrm{H}_{2} 0\right)$ of 5.1, 5.2, and 5.3 in the soil 117 depths 0-10, 10-35 and 35-65 cm, respectively. Two neighbouring stands of pure beech and

118 spruce were examined. Both stands originate from natural regeneration following a clearcut of 119 preceding high forest. At the start of measurements presented in this study, both stands featured 120 trees about 12-14 years of age. The beech stand was composed of dense groups of beech trees 121 with a few scattered gaps colonised by Calamagrostis epigejos L. The structure of the spruce 122 stand was similar to that of beech, however no grass cover was present due to shading by spruce 123 trees. Detailed description of the site characteristics can be found in Konôpka et al.(2013).

\section{Size distribution, biomass and foliage sampling}

126 Five circular experimental plots were established in each stand in March 2009. The plots were $127100 \mathrm{~cm}$ in radius and contained around 40 trees each. The plots were randomly positioned 128 within each stand, but at a distance of at least 5 canopy heights from each other. All trees within 
each plot (PlotTrees thereafter) were tagged. Height and diameter $\mathrm{d}_{0}$ (diameter at ground level)

130 of all tagged trees were measured in September of 2009, 2010 and 2011.

131 During late summer 2011, 40 beech and 40 spruce trees were selected just outside the 132 experimental plots and their foliage sampled from upper, middle and lower crown sections

133 (FolTrees thereafter). Ten trees each were selected from the following four crown classes within

134 the canopy: dominant, co-dominant, intermediate and overtopped (Kraft, 1884). Care was taken

135 to cover the entire diameter distribution found in experimental plots. Then, three leaves were 136 randomly selected and taken from each crown section of beech trees (9 leaves per tree). In

137 spruce, 30 needles were collected from each crown section and in each of the following age 138 cohorts (by year of needle set): 2011, 2010, 2009, 2008 and, rarely, 2007. All foliage samples

139 were scanned on a flatbed scanner (EPSON Expression 10000), oven-dried and weighed. Leaf 140 area of sampled foliage was established by WinFOLIA (Regent Instruments Inc., Quebec). 141 Specific leaf area (SLA) of individual leaves or needles was calculated as a ratio of foliage area 142 and dry mass.

143 A further 80 beech and 100 spruce trees were selected from each stand for destructive sampling

144 in early September 2011 (BiomTrees thereafter). All tree compartments with the exception of

145 fine roots thinner than $2 \mathrm{~mm}$ were harvested. Slightly fewer beech trees were sampled as the 146 population of this species was more uniform in size than spruce. Height and $\mathrm{d}_{0}$ of all sampled 147 trees were established prior to destructive sampling. Harvested trees were divided into foliage 148 and other (woody) compartments, dried until constant weight and weighed. Out of the 100 149 harvested spruce trees, 30 were randomly selected to establish the contribution of needle cohorts 150 to total needle mass. All needles found on these trees were collected, divided to 5 cohorts (2011 151 through 2007), dried and weighed

152 Stocking density and size distribution data from experimental plots were used for inter-specific 153 comparisons between beech and spruce stands. Foliage size distribution data formed the basis 
154 for characterisation of vertical leaf size profiles of the canopy. Data on biomass compartment

155 and foliage characteristics gathered outside experimental plots were used for biomass model 156 parameterisations.

\section{Estimations of biomass equations, LA and LAI}

159 Dry weight data of biomass compartments measured in BiomTrees were used to construct

160 biomass equations after Pajtík et al. (2008). The following model was used to estimate dry 161 weights of stems, branches, coarse roots and foliage of individual trees:

$W_{i}=e^{\left(b_{0}+b_{1} \ln d_{0}\right)} \lambda$

Where $W_{i}$ is dry biomass of a tree component $i, d_{0}$ is stem diameter at base, $b_{0}$, and $b_{1}$ are coefficients to be estimated and $\lambda$ is logarithmic transformation bias. Site-specific biomass equation parameters are listed in Table 2.

168

Specific leaf area (SLA) of foliage taken from FolTrees was calculated as the ratio between projected leaf area of foliage sample and its dry mass. Once the relationship between foliage

171 biomass and tree size has been established, total leaf area of an individual tree (LA)

172 dependent on $\mathrm{d}_{0}$ can be calculated as follows:

173

$$
L A=S L A^{*}\left(e^{\left(b_{0}+b_{1} \ln d_{0}\right)} \lambda\right)
$$

176 Where $L A$ is total leaf area per tree, $S L A$ is specific leaf area in $\mathrm{m}^{2} \mathrm{~g}^{-1}, b_{0}$ and $b_{1}$ are site-

177 specific coefficients of leaf biomass equation (1), $d_{0}$ is stem diameter at the base and $\lambda$ is

178 logarithmic transformation bias. 
180 In each circular permanent experimental plot, we calculated LAI by dividing the sum of LA

181 of all PlotTrees found within the plot by its area:

$$
L A I_{j}=\frac{\sum_{i=1}^{n} L A_{i j}}{S_{j}}
$$

184 where $n$ is the number of trees within a plot, $L A_{i j}$ is the leaf area of $i$-th tree on $j$-th plot, and $S_{j}$

185 is the area of the $j$-th plot. This calculation is fairly straightforward in European beech due to

186 the presence of a single cohort of leaves. In Norway spruce, however, the variation of SLA in needle cohorts was also taken into account. For each needle cohort, $L A$ of needles from all trees present within a permanent plot can be calculated as follows:

$$
L A_{j k}=\sum_{i=1}^{n}\left(W_{i} * P_{k} * S L A_{k}\right)
$$

where $n$ is the number of trees within a plot, $W_{i}$ is the dry needle biomass of $i$-th tree, $P_{k}$ is the proportion of $k$-th cohort from the total and $S L A_{k}$ is the specific leaf area of the $k$-th needle cohort. Mean SLA for the entire vertical profile of the canopy was used for each cohort. Based on an analysis of trees harvested at the site, we established that $P_{k}$ in spruce is stable and independent of $d_{0}$ (Supplementary Figure S1), therefore mean values of $P_{k}$ were used across

197 all diameter classes. $L A$ of all spruce trees found within each plot was then obtained by 198 summing up leaf areas of the five needle cohorts.

\section{Data analysis}


201 All stand-level observations were averaged to plot level $(\mathrm{N}=5)$, differences between species

202 were compared by one-way ANOVA and considered significant at $\mathrm{P}<0.05$. All variables were 203 checked for the homogeneity of variance (Levene's test) and normality of distribution

204 (D’Agostino and Pearson Test). Repeated measures ANOVA was used to compare the 205 development of LAI in the two stands over the period of observation. Two-way ANOVA was 206 used to assess the effect of species and canopy position on SLA, followed by Tukey's 207 multiple comparison test. Data were log-transformed where they did not satisfy ANOVA 208 assumptions. Linear or exponential equations were fitted to individual tree data where 209 appropriate, using least squares fit. Model parameters were assessed for differences between 210 species (stem increment per unit leaf mass) or from specific value (needle cohort contribution 211 to total) by extra sum-of-squares F test.

\section{Results}

213 Although very similar in age, the two studied ecosystems did differ in several standard forest 214 stand characteristics (Table 1). Beech trees were significantly taller than spruce, while spruce 215 trees had a larger diameter at base, resulting in a significantly larger height/diameter ratio in 216 beech than in spruce. The difference in height to diameter ratio between the two species is 217 evident throughout the diameter size distribution (Supplementary Figure S2). On the other hand, 218 there was no difference in the number of trees per unit area, mean stem volume and basal area.

220 Measurements of foliage collected from 40 beech and 40 spruce FolTrees reveal that individual 221 leaf size is far more conservative in spruce than in beech (coefficient of variance 0.29 and 0.53 222 respectively, Figure 1). Within the stem diameter distribution present in the stands at the time 223 of measurement, beech leaf area increases by $83 \%$ from the $25^{\text {th }}$ to the $75^{\text {th }} d_{0}$ percentile. In 224 spruce, however, the comparable increase in individual needle area is only $38 \%$. Similarly, the 
spread of leaf size between leaves collected at the top and bottom of the canopy represents $84 \%$ of mean leaf size at mean $\mathrm{d}_{0}$ in beech, but only $28 \%$ in spruce.

Analogous to foliage area, we observed how SLA is affected by tree size and foliage position

within the canopy (Figure 2). The highest values for both species were recorded in overtopped trees growing underneath the main canopy. In contrast to leaf area, we did not observe such a strong effect of $d_{0}$ on the differentiation of SLA values between the two species. The spread of mean SLA at the top and bottom of the canopy represents $43 \%$ of mean SLA in beech and $33 \%$ in spruce. SLA of foliage growing in the middle of the canopy on the mean tree was $273 \mathrm{~cm}^{2} \cdot \mathrm{g}^{-}$

$234{ }^{1}$ in beech and $87 \mathrm{~cm}^{2} \cdot \mathrm{g}^{-1}$ in spruce.

Ten beech and ten spruce FolTrees were selected from each of the four crown classes considered in this study to evaluate the effect of tree size on SLA (Figure 3). We observed no difference between the two species in the effect of crown class on SLA. Dominant and co-dominant trees show the same SLA in beech $(\mathrm{p}=0.812)$ and in spruce $(\mathrm{p}=0.986)$. Intermediate and suppressed trees, however, have higher SLA than dominant trees in both species $(p<0.001)$. Foliage 241 position within an individual tree crown does not affect SLA in overtopped trees in beech $242(\mathrm{p}=0.856)$ or spruce $(\mathrm{p}>0.999)$, trees in other canopy classes however do show a significant effect of foliage position on SLA $(\mathrm{p}<0.026)$.

Destructively sampled BiomTrees were used to construct biomass equations linking biomass 246 compartments to diameter at base (Supplementary Table 1). Figure 4A shows total foliage mass 247 of beech and spruce trees across the diameter distribution observed in this study. It is clear that spruce trees of the same size support more foliage mass than beech trees. At the same time, 249 beech foliage has greater SLA in all tree sizes under investigation (Figure 4B). Using data for 
whole tree foliage mass in combination with mean SLA, we observe that there is very little

251 difference in whole tree leaf area between beech and spruce trees (Figure 4C).

The observed similarity of whole tree leaf area of beech and spruce trees was reflected in calculated LAI. As already mentioned, basal area and tree density did not differ between the two stands. Coupled with very similar total leaf area of individual trees, it is not surprising that LAI did not differ between beech and spruce ( $\mathrm{p}=0.865$, Figure 5). From 2009 through 2011, modelled LAI increased from 11.4 to $14.9 \mathrm{~m}^{2} \mathrm{~m}^{-2}$ in beech and 10.3 to $14.2 \mathrm{~m}^{2} \mathrm{~m}^{-2}$ in spruce.

Finally, biomass equations and data describing foliage cover in both species were used to compare wood production efficiency expressed as wood mass produced per unit foliage mass or unit foliage area. Taller trees were always more efficient in using unit foliage to produce unit stem biomass (Figure 6). The slope of linear regressions describing the relationship between foliage efficiency and tree height of all trees measured in permanent plots was always positive and significantly different from zero $(\mathrm{P}<0.0001)$. Interestingly, as the stands grew older, the advantage of dominant and co-dominant trees in terms of wood production efficiency was slowly eroding - but only in beech. A tree $1 \mathrm{~m}$ taller than its competitors produced 0.63 more grams of stem wood per gram foliage in 2009 , but this advantage in foliage productivity decreased to $0.33 \mathrm{~g} \mathrm{~g}^{-1}$ in 2011 ( $\left.\mathrm{P}=0.0007\right)$. This decrease was not evident in spruce, where the slope of the linear regression was 0.11 in 2009 and 0.09 in $2011(\mathrm{P}=0.304)$. Similar to foliage mass, we observed the same dynamic when plotting the stem production efficiency expressed 271 per unit of foliage area against tree height; a decrease of regression slope from $36.3 \mathrm{~g}$ of stem mass per metre square of foliage for every metre of height in 2009 to 22.7 in 2011 in beech

$273(\mathrm{P}<0.0001)$. In spruce, the slope did not change over the period of observation; $19.2 \mathrm{~g} \mathrm{~m}^{-2} \mathrm{~m}^{-1}$ 274 in 2009 and $10.1 \mathrm{~g} \mathrm{~m}^{-2} \mathrm{~m}^{-1}$ in $2011(\mathrm{P}=0.424)$. 


\section{Discussion}

278 Both stands considered in this study originate from natural regeneration following the removal 279 of original tall forest. It is to be expected that not all trees are of the same age, however we 280 established that the cohort of trees currently growing on the site is between 12 and 14 years old. 281 The stands were dense, at the time of the study there was no difference in the number of trees 282 per hectare. Beech trees were marginally taller, while spruce trees had thicker stems at the base. However, there was no difference in basal area, leading us to the assertion that any differences in foliage characteristics are due to differences in genetics and growth habit, rather than because of different tree size or stocking density and resulting competition.

\section{Leaf level}

Individual leaves with the largest area were always found at the top of the canopy, both in beech and in spruce. Leaves and needles were progressively smaller with increasing canopy depth, this differentiation of single leaf size appears to be stronger in beech than in spruce. Shorter trees had smaller leaves than taller trees, owing to the shading of their entire crowns by taller trees. Contrasting evidence exists on the effect of shading on individual leaf size. Our results in beech are in disagreement those of Barna et al. (2004) and Tognetti et al. (1998) who found

294 that the size of foliage increased with shading, but correspond with the study by Carnham 295 (1988) who found larger leaf size at high light levels in Acer saccharum Marsh. and Fagus 296 grandiflora Ehrh. Similarly, Niinemetz and Kull (1995) found no effect of irradiance on 297 projected needle area in spruce and Gebauer et al. (2011) indicate that needle size increases 298 with light intensity in most but not all of the 57 spruce provenances they compared. The wide 299 variation in the relationship between leaf size and light intensity points to substantial plasticity 
in both species considered in this study. In general, Dombroskie et al. (2012) propose that

301 smaller leaves are favoured under low light exposure because they minimize overlap of closely spaced adjacent leaves and they are subject to a trade-off of selection favouring high number/low size strategy which in turn maximizes the size of the reserve bud bank .

SLA, calculated as leaf area per unit mass, was found to be the smallest at the top of the

306 canopy in full light conditions and increases with shading both in beech and in spruce. Larger

307 SLA with increasing shading is likely an adaptation for more efficient light interception in

308 low light conditions (Niinemets et al., 2001). SLA was found to be greatest at the bottom

309 compared to the top of the crown in 13- to 82-year-old Norway spruce (Merilo et al., 2009)

310 and in spruce, beech and fir seedlings (Stancioiu and O'hara, 2006). In this study, both beech

311 and spruce show the same decreasing trend, graphs in Figure 2 indicate that leaf and needle

312 SLA will decrease further as the stands mature before stabilising. Significant differences in

313 SLA between socio-ecological classes of trees within the canopy were found. Dominant, co-

314 dominant and intermediate crown have shown strong effect of crown depth on SLA. Foliage

315 SLA of overtopped trees, owing to growth in share conditions, did not differ between the top

316 and the bottom parts of tree crowns. The optimal partitioning theory suggests that a plant

317 invests primarily to those compartments which are crucial for acquiring the most limiting

318 resource (Niklas, 2004). Maximum available light must be captured by overtopped trees,

319 leading to construction of large foliage area with minimum mass invesment.

\section{$321 \quad$ Tree level}

As expected, beech trees had substantially smaller foliage mass than spruce trees of

323 comparable size. However, we have established that the latest cohort of spruce needles

324 constituted only $34 \%$ of the total needle mass. Comparing only the current year beech and 
spruce foliage mass shows that the two species invest exactly the same amount of resource to building their photosynthetic apparatus in a given year. Considering the effect of shading on SLA, mean SLA per tree is far larger in small (overtopped) trees, but approximates to that of spruce in lager (dominant) individuals. Higher SLA of shaded foliage in young beech stands was recorded by Closa et al. (2010). Barna (2004) showed lower values of SLA in dominant and co-dominant beech trees than in subdominant individuals. Our observations of beech SLA

331 are in the same range as those of Barna (2004) who report 120 to $460 \mathrm{~cm}^{2} \cdot \mathrm{g}^{-1}$, Closa et al. 332 (2010) with values between $180-480 \mathrm{~cm}^{2} \cdot \mathrm{g}^{-1}$, and those of Leuschner et al. (2006) who report a range between $190-240 \mathrm{~cm}^{2} \cdot \mathrm{g}^{-1}$. As for the SLA of spruce needles, our values are higher than those of Heger and Sterba (1985) who found SLA of $30-70 \mathrm{~cm}^{2} \cdot \mathrm{g}^{-1}$ in a 17 -yearold stand, however the needles in the upper and middle part of the largest trees in our study were inside this range. Taken together, the observed contrasting trends of leaf area per tree and SLA mean that there is little difference in total leaf area per tree between beech and spruce trees of the same size. Despite one being conifer and the other broadleaf, beech and spruce trees of the same diameter class support nearly identical leaf area.

\section{Stand level}

Reflecting foliage area per tree and stand density, LAI indicates the potential of forest

343 stands to utilise incident radiation to produce biomass. Stand LAI was steadily increasing during 344 the period of observation, reaching approximately $15 \mathrm{~m}^{2} \mathrm{~m}^{-2}$ in 2011. Most studies indicate LAI 345 in a variety of forest tree species below $10 \mathrm{~m}^{2} \cdot \mathrm{m}^{-2}$ (e.g. (Bréda, 2003; Leuschner et al., 2006), 346 but higher values are also reported, albeit considered as extreme (e.g. (Ford, 1982; Albrektson, 347 1984; Bolstad and Gower, 1990). Waring and Schlesinger (1985) posit that very dense foliage 348 can be found in some coniferous forests, exceptionally reaching LAI values as high as $20 \mathrm{~m}^{2} \cdot \mathrm{m}^{-}$ 3492 . Nock et al. (2008) found a relationship between tree size and LAI in Acer saccharum and 
Betula alleghaniensis, trees with DBH of $30 \mathrm{~cm}$ had LAI of 7.5 and $8.5 \mathrm{~m}^{2} . \mathrm{m}^{-2}$, but trees with

351 DBH of $70 \mathrm{~cm}$ showed LAI of 4.0 and $6.0 \mathrm{~m}^{2} \cdot \mathrm{m}^{-2}$ in Acer and Betula, respectively. There are 352 several reasons why we observed very high LAI values; methodological, ontogenetic and 353 possibly climatic. The diameter-based allometric method of LAI estimation has been reported 354 to show values higher than other methods (Marshall and Waring, 1986). The aggrading nature 355 of our naturally regenerated stands may have caused the increasing LAI, which may reverse in 356 the future as the stands age and self-thin. Finally, the exposition of the site is south-westerly, 357 providing optimal insolation for these young stands.

Wood production efficiency, expressed as unit stem increase per unit foliage, did differ between

360 beech and spruce. Stem increment per unit leaf mass was far higher in beech compared to 361 spruce, driven by retention of older needle cohorts in spruce which increases foliage mass. 362 Dominant beech trees had significantly higher efficiency than overtopped trees, this advantage 363 of taller trees was not as evident in spruce. A possible explanation for this difference can be 364 that needle-shaped leaves can be arranged in a pattern that bounces the incoming radiation over 365 a larger number of leaves deeper in the canopy (Sprugel, 1989). This effects increases 366 photosynthesis of overtopped spruce trees by reducing the energy wastage that occurs when 367 light falls on horizontally positioned beech leaves at the top of the canopy that are already light368 saturated. However, when plotted against leaf area, wood production efficiency did not differ 369 between the two species. This suggests that it is higher leaf thickness (Aranda et al., 2004) 370 rather than leaf area at the top of the canopy that confers stem growth advantage in dominant 371 beech trees.

\section{Conclusion}


Stands of beech and spruce around Central Europe occur as monospecific stands, but also as

various mixtures of the two species. This study compared the development of foliage and canopy in the two species, with the view of contrasting their light utilisation strategies. Leaf area per tree, stand LAI and stem increment per unit leaf area were found not to differ between beech and spruce in our stands, suggesting that stands of both species are utilising close to maximum available light energy. We found that morphology of beech foliage is more plastic that than of spruce, possibly contributing to the competitive advantage of beech in locations where the two species co-occur.

\section{References}

Albrektson, A., 1984. Sapwood basal area and needle mass of Scots pine (Pinus sylvestris L.) trees in central Sweden. Forestry 57, 35-43.

Aranda, I., Pardo, F., Gil, L., Pardos, J.A., 2004. Anatomical basis of the change in leaf mass per area and nitrogen investment with relative irradiance within the canopy of eight temperate tree species. Acta Oecol 25, 187-195.

Barna, M., 2004. Adaptation of European beech (Fagus sylvatica L.) to different ecological conditions: leaf size variation. Pol J Ecol 52, 35-45.

Bolstad, P.V., Gower, S.T., 1990. Estimation of leaf area index in fourteen southern Wisconsin forest stands using a portable radiometer. Tree Phys 7, 115-124.

Bréda, N.J.J., 2003. Ground-based measurements of leaf area index: A review of methods, instruments and current controversies. J Exp Bot 54, 2403-2417.

Bussotti, F., Borghini, F., Celesti, C., Leonzio, C., Bruschi, P., 2000. Leaf morphology and macronutrients in broadleaved trees in central Italy. Trees 14, 361-368.

Canham, C.D., 1988. Growth and canopy architecture of shade-tolerant trees: response to canopy gaps. Ecology 69, 786-795.

Chen, J.M., Rich, P.M., Gower, S.T., Norman, J.M., Plummer, S., 1997. Leaf area index of boreal forests: theory, techniques, and measurements. Journal of Geophysical Research: Atmospheres (1984-2012) 102, 29429-29443.

Cienciala, E., Exnerova, Z., Schelhaas, M.J., 2008. Development of forest carbon stock and wood production in the Czech Republic until 2060. Ann For Sci 65, -.

Claesson, S., Sahlén, K., Lundmark, T., 2001. Functions for biomass estimation of young Pinus sylvestris, Picea abies and Betula spp. from stands in northern Sweden with high stand densities. Scand J For Res 16, 138-146.

Closa, I., Irigoyen, J.J., Goicoechea, N., 2010. Microclimatic conditions determined by stem density influence leaf anatomy and leaf physiology of beech (Fagus sylvatica L.) growing within stands that naturally regenerate from clear-cutting. Trees 24, 1029-1043.

Delagrange, S., Messier, C., Lechowicz, M.J., Dizengremel, P., 2004. Physiological, morphological and allocational plasticity in understory deciduous trees: importance of plant size and light availability. Tree Phys 24, 775-784. 
Dombroskie, S.L., Aarssen, L.W., 2012. The leaf size/number trade-off within species and within plants for woody angiosperms. Plant Ecology and Evolution 145, 38-45.

Ellenberg, H., Leuschner, C., 1996. Vegetation mitteleuropas mit den alpen. Ulmer, Stuttgart.

Fehrmann, L., Kleinn, C., 2006. General considerations about the use of allometric equations for biomass estimation on the example of Norway spruce in central Europe. For Ecol Manage 236, 412-421.

Ford, E.D., 1982. High productivity in a polestage Sitka spruce stand and its relation to canopy structure. Forestry 55, 1-17.

Gebauer, R., Volařík, D., Urban, J., Børja, I., Nagy, N.E., Eldhuset, T.D., Krokene, P., 2011. Effect of thinning on anatomical adaptations of Norway spruce needles. Tree Phys 31, 1103-1113.

Hager, H., Sterba, H., 1985. Specific leaf area and needle weight of Norway spruce (Picea abies) in stands of different densities. Can J For Res 15, 389-392.

Hallik, L., Niinemets, Ü., Wright, I.J., 2009. Are species shade and drought tolerance reflected in leaf-level structural and functional differentiation in Northern Hemisphere temperate woody flora? New Phytol 184, 257-274.

Herbert, D.A., Fownes, J.H., 1999. Forest productivity and efficiency of resource use across a chronosequence of tropical montane soils. Ecosystems 2, 242-254.

Jack, B.S., Sheffield, M.C.P., McConville, D.J., others, 2002. Comparison of growth efficiency of mature longleaf and slash pine trees. General Technical Report SRS-48, 81-85.

Johansson, T., 1996. Estimation of canopy density and irradiance in 20-to 40-year-old birch stands (Betula pubescens Ehrh. and Betula pendula Roth). Trees 10, 223-230.

Kantor, P., Šach, F., Černohous, V., others, 2009. Development of foliage biomass of young spruce and beech stands in the mountain water balance research area. J For Sci 55, 5162.

King, D.A., 1990. The adaptive significance of tree height. Am Nat, 809-828.

Konôpka, B., Pajtík, J., Moravčík, M., Lukac, M., 2010. Biomass partitioning and growth efficiency in four naturally regenerated forest tree species. Basic Appl Ecol 11, 234-243.

Konôpka, B., Pajtík, J., Šebeň, V., Bošel’a, M., Máliš, V., Priwitzer, T., Pavlenda, P., 2013. The research site Vrchslatina - an experimental design and the main aims. Lesnícky časopis Forestry Journal 59, 203-213.

Kraft, G., 1884. Beiträge zur lehre von den durchforstungen, schlagstellungen und lichtungshieben. Klindeorth.

Kull, O., Broadmeadow, M., Kruijt, B., Meir, P., 1999. Light distribution and foliage structure in an oak canopy. Trees 14, 55-64.

Leuschner, C., Vols s, S., Foetzki, A., Clases, Y., 2006. Variation in leaf area index and stand leaf mass of European beech across gradients of soil acidity and precipitation. Plant Ecol. 186, 247-258.

Long, J.N., Smith, F.W., 1990. Determinants of stemwood production in Pinus contorta var. latifolia forests: the influence of site quality and stand structure. J Appl Ecol, 847-856.

Marshall, J.D., Waring, R.H., 1986. Comparison of methods of estimating leaf-area index in old-growth Douglas-fir. Ecology, 975-979.

Merilo, E., Tulva, I., Räim, O., Kükit, A., Sellin, A., Kull, O., 2009. Changes in needle nitrogen partitioning and photosynthesis during 80 years of tree ontogeny in Picea abies. Trees 23, 951-958.

Milla, R., Reich, P.B., Niinemets, Ü., Castro-Díez, P., 2008. Environmental and developmental controls on specific leaf area are little modified by leaf allometry. Funct Ecol 22, 565576. 
Niinements, U., Kull, O., 1995. Effects of light availability and tree size on the architecture of assimilative surface in the canopy of Picea abies: variation in needle morphology. Tree Phys 15, 307-315.

Niinemets, Ü., 2010. A review of light interception in plant stands from leaf to canopy in different plant functional types and in species with varying shade tolerance. Ecol Res 25, 693-714.

Niinemets, Ü., Ellsworth, D.S., Lukjanova, A., Tobias, M., 2001. Site fertility and the morphological and photosynthetic acclimation of Pinus sylvestris needles to light. Tree Phys 21, 1231-1244.

Niklas, K.J., 2004. Plant allometry: is there a grand unifying theory? Biological reviews 79, 871-889.

Nock, C.A., Caspersen, J.P., Thomas, S.C., 2008. Large ontogenetic declines in intra-crown leaf area index in two temperate deciduous tree species. Ecology 89, 744-753.

Oguchi, R., Hikosaka, K., Hirose, T., 2005. Leaf anatomy as a constraint for photosynthetic acclimation: differential responses in leaf anatomy to increasing growth irradiance among three deciduous trees. Plant, Cell Environ. 28, 916-927.

Pajtík, J., Konôpka, B., Lukac, M., 2008. Biomass functions and expansion factors in young Norway spruce (Picea abies [L.] Karst) trees. For Ecol Manage 256, 1096-1103.

Pajtík, J., Konôpka, B., Lukac, M., 2011. Individual biomass factors for beech, oak and pine in Slovakia: a comparative study in young naturally regenerated stands. Trees $25,277-288$.

Paquette, A., Bouchard, A., Cogliastro, A., 2007. Morphological plasticity in seedlings of three deciduous species under shelterwood under-planting management does not correspond to shade tolerance ranks. For Ecol Manage 241, 278-287.

Paz, H., 2003. Root/Shoot allocation and root architecture in seedlings: variation among forest Sites, microhabitats, and ecological groups I. Biotropica 35, 318-332.

Pearcy, R.W., Muraoka, H., Valladares, F., 2005. Crown architecture in sun and shade environments: assessing function and trade-offs with a three-dimensional simulation model. New Phytol 166, 791-800.

Pickup, M., Westoby, M., Basden, A., 2005. Dry mass costs of deploying leaf area in relation to leaf size. Funct Ecol 19, 88-97.

Portsmuth, A., Niinemets, Ü., 2007. Structural and physiological plasticity in response to light and nutrients in five temperate deciduous woody species of contrasting shade tolerance. Funct Ecol 21, 61-77.

Richardson, A.D., Ashton, P.M.S., Berlyn, G.P., McGroddy, M.E., Cameron, I.R., 2001. Within-crown foliar plasticity of western hemlock, Tsuga heterophylla, in relation to stand age. Ann. Bot. 88, 1007-1015.

Sanchez-Gomez, D., Valladares, F., Zavala, M.A., 2006. Functional traits and plasticity in response to light in seedlings of four Iberian forest tree species. Tree Phys 26, 1425-1433.

Shipley, B., 2006. Net assimilation rate, specific leaf area and leaf mass ratio: which is most closely correlated with relative growth rate? A meta-analysis. Funct Ecol 20, 565-574.

Sprugel, D.G., 1989. The relationship of evergreenness, crown architecture, and leaf size. Am Nat, 465-479.

Stancioiu, P.T., O'hara, K.L., 2006. Morphological plasticity of regeneration subject to different levels of canopy cover in mixed-species, multiaged forests of the Romanian Carpathians. Trees 20, 196-209.

Steele, M.J., Yeoman, M.M., Coutts, M.P., 1990. Developmental changes in Sitka spruce as indices of physiological age. New Phytol 114, 111-120.

Tognetti, R., Minotta, G., Pinzauti, S., Michelozzi, M., Borghetti, M., 1998. Acclimation to changing light conditions of long-term shade-grown beech (Fagus sylvatica L.) seedlings of different geographic origins. Trees 12, 326-333. 
512 Waring, R.H., Schlesinger, W.H., others, 1985. Forest ecosystems. concepts and management. $513 \quad$ Academic Press.

514 West, G.B., Enquist, B.J., Brown, J.H., 2009. A general quantitative theory of forest structure and dynamics. Proceedings of the National Academy of Sciences 106, 7040-7045.

516 Wirth, C., Schumacher, J., Schulze, E.D., 2004. Generic biomass functions for Norway spruce in Central Europe - a meta-analysis approach toward prediction and uncertainty estimation. Tree Phys 24, 121-139.

Xiao, C.-W., Ceulemans, R., 2004. Allometric relationships for below-and aboveground biomass of young Scots pines. For Ecol Manage 203, 177-186. 


\begin{tabular}{lcccc}
\hline & European beech & Norway spruce & d.f./F & P \\
\hline Number of trees $\left(\right.$ ths. $\left.\mathrm{ha}^{-1}\right)$ & $124.3 \pm 11.6$ & $99.4 \pm 6.6$ & $1 / 3.45$ & 0.100 \\
Mean tree height $(\mathrm{cm})$ & $295.3 \pm 22.2$ & $213.0 \pm 5.3$ & $1 / 13.63$ & $\mathbf{0 . 0 0 6}$ \\
Mean diameter $\mathrm{d}_{0}^{*}(\mathrm{~cm})$ & $2.42 \pm 0.11$ & $3.19 \pm 0.11$ & $1 / 25.57$ & $\mathbf{0 . 0 0 1}$ \\
H/D ratio $\left(\mathrm{cm}^{\left.-\mathrm{cm}^{-1}\right)}\right.$ & $125.9 \pm 8.5$ & $76.3 \pm 2.5$ & $1 / 31.50$ & $\mathbf{0 . 0 0 1}$ \\
Mean stem volume $\left(\mathrm{cm}^{3}\right)$ & $526.6 \pm 56.7$ & $645.9 \pm 34.5$ & $1 / 3.22$ & 0.110 \\
Basal area $\mathrm{d}_{0} *\left(\mathrm{~m}^{2} . \mathrm{ha}^{-1}\right)$ & $356.2 \pm 35.5$ & $334.6 \pm 28.5$ & $1 / 0.22$ & 0.648
\end{tabular}

\section{Tables}

Table 1 Stand characteristics for European beech and Norway spruce in November 2011, approximately 13 years after natural regeneration (means $\pm \mathrm{se}, \mathrm{p}$ values at $\mathrm{N}=5$ ). 
529 Table 2 Site-specific biomass equation parameters for European beech (Fagus sylvatica) and

530 Norway spruce (Picea abies). Diameter at based is used as the single predictor in all models

531 estimating compartment biomass.

\begin{tabular}{llccccc}
\hline Species & Compartment & $\mathrm{b}_{\mathrm{o}}(\mathrm{S} . \mathrm{E}.) \mathrm{P}$ & $\mathrm{b}_{1}(\mathrm{~S} . \mathrm{E}.) \mathrm{P}$ & $\mathrm{R}^{2}$ & $\mathrm{MSE}$ & $\Lambda(\mathrm{S} . \mathrm{D})$. \\
\hline \multirow{3}{*}{ Beech } & Leaves & $-6.576(0.256)<0.001$ & $3.085(0.081)<0.001$ & 0.960 & 0.102 & $1.047(0.308)$ \\
& Woody mass & $-3.357(0.191)<0.001$ & $2.889(0.060)<0.001$ & 0.974 & 0.056 & $1.027(0.238)$ \\
& Whole tree & $-3.318(0.188)<0.001$ & $2.900(0.060)<0.001$ & 0.975 & 0.055 & $1.026(0.234)$ \\
& Needles & $-3.079(0.171)<0.001$ & $2.432(0.054)<0.001$ & 0.964 & 0.106 & $1.053(0.366)$ \\
Spruce & Woody mass & $-1.719(0.138)<0.001$ & $2.283(0.043)<0.001$ & 0.974 & 0.069 & $1.035(0.296)$ \\
& Whole tree & $-1.489(0.134)<0.001$ & $2.321(0.042)<0.001$ & 0.976 & 0.065 & $1.034(0.295)$ \\
\hline
\end{tabular}

532 


\section{Figures}

534 Figure 1 Single leaf and needle area at three different canopy levels in European beech (A) and

535 Norway spruce (B). Solid lines represent best fit models for top, middle and bottom of individual tree 536 crown.
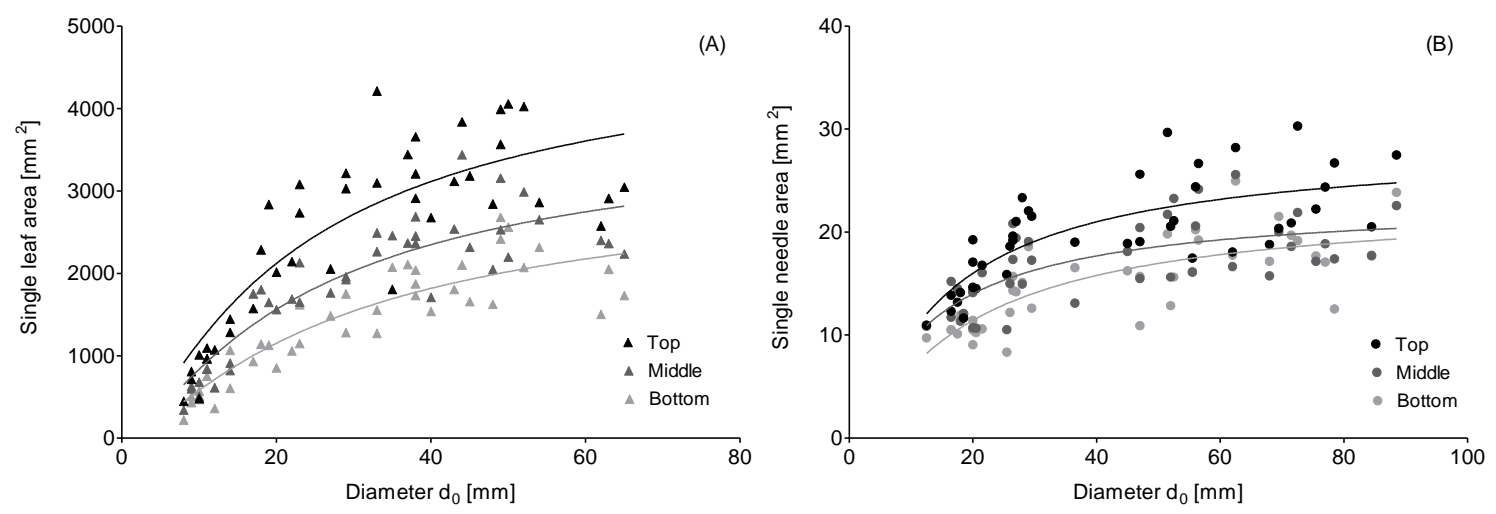

538 Figure 2 Specific leaf area at three different canopy levels in European beech (A) and

539 Norway spruce (B). Solid lines represent best fit models for top, middle and bottom of individual 540 tree crown.
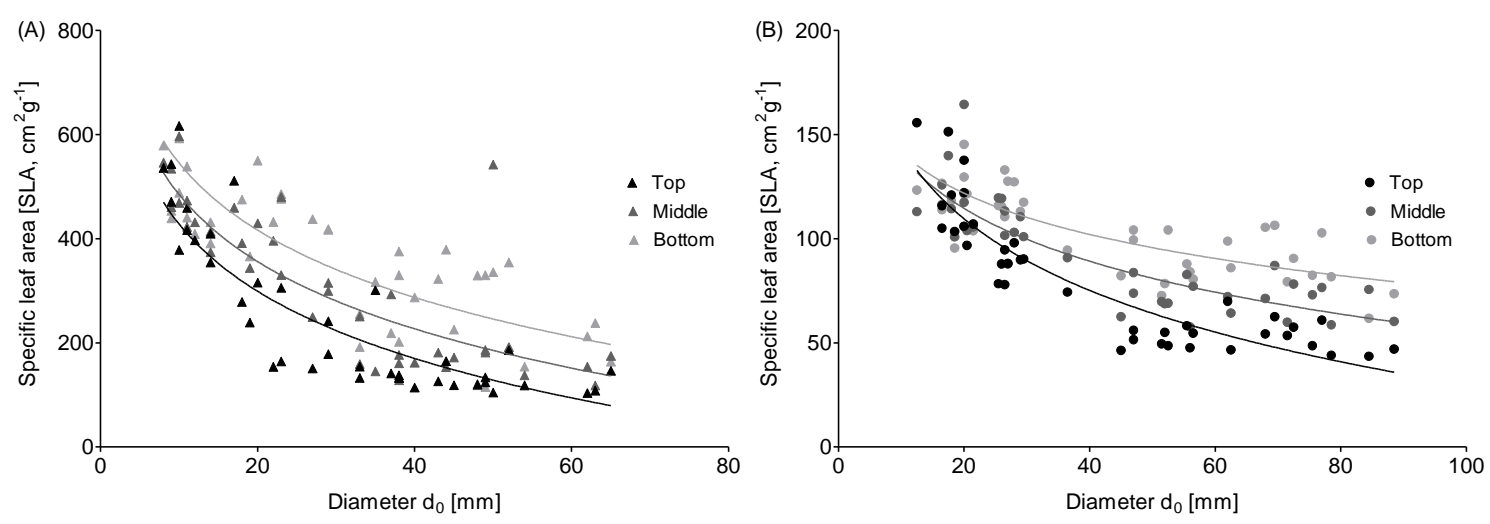
544 Figure 3 Specific leaf area of European beech (A) and Norway spruce (B) foliage as affected by

545 canopy position and socio-ecological status of individual trees $\left(\mathrm{cm}^{2} \mathrm{~g}^{-1}, \mathrm{~N}=10\right.$ in each class, mean \pm $546 \mathrm{sd})$.
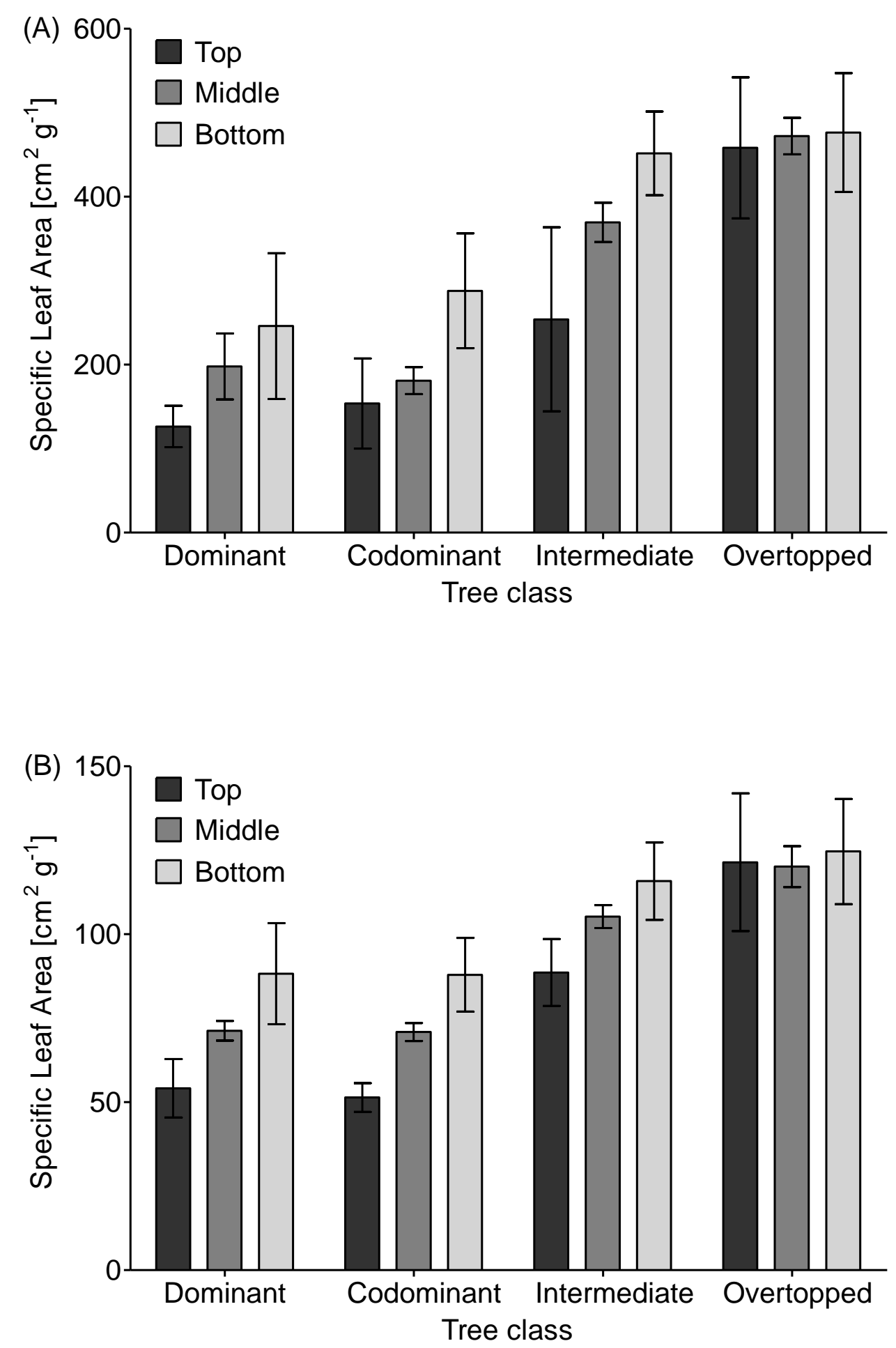
548 Figure 4 Whole tree foliage mass (A), specific leaf area (B) and whole tree leaf area (C) of naturally 549 regenerated European beech and Norway spruce trees. Dotted lines in pane C represent $95 \%$ confidence 550 interval of fitted line.

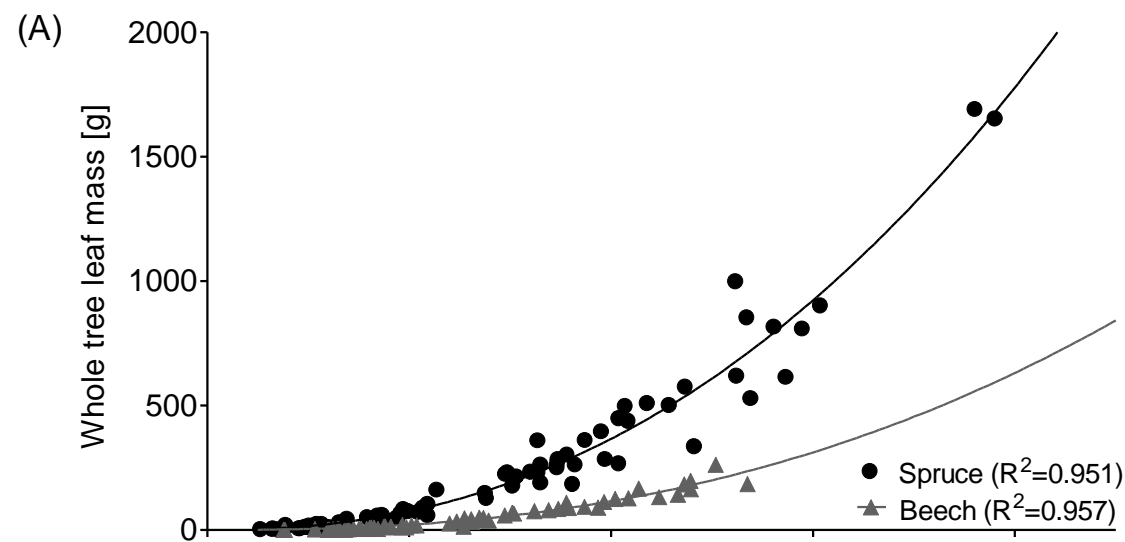

(B)

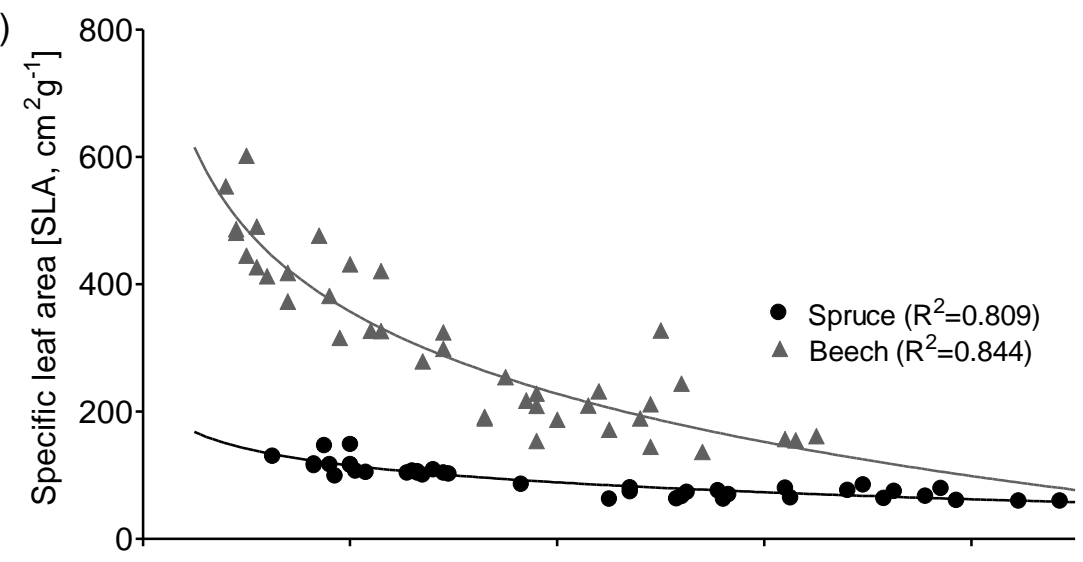

(C)

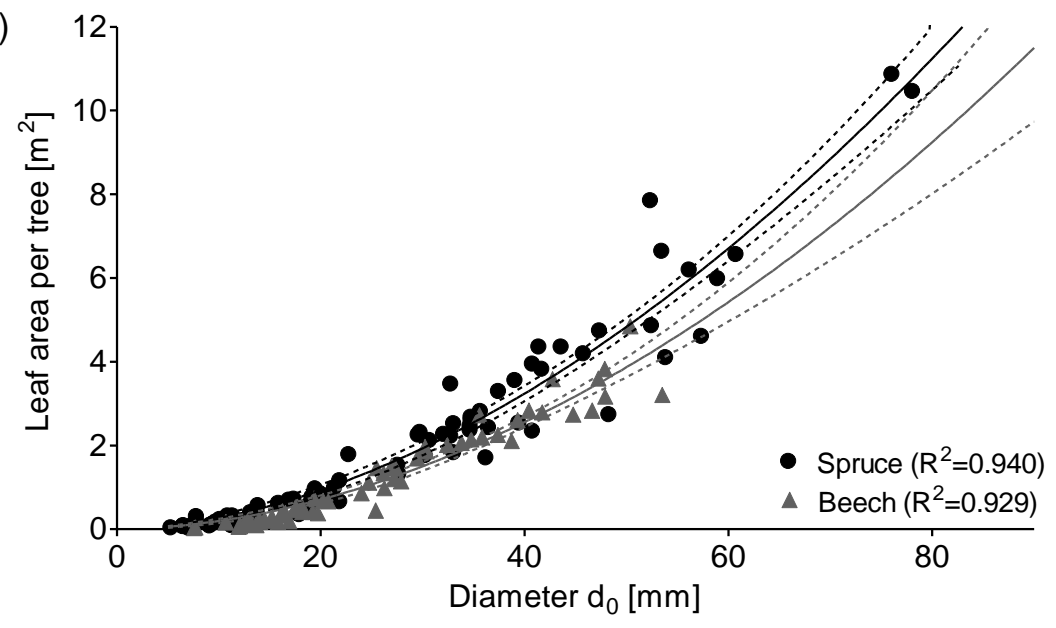


553 Figure 5 Leaf Area Index (LAI) in naturally regenerated stands of European beech and Norway spruce

554 trees measured in permanent plots (mean $\pm \mathrm{SD}, \mathrm{N}=5$ ).

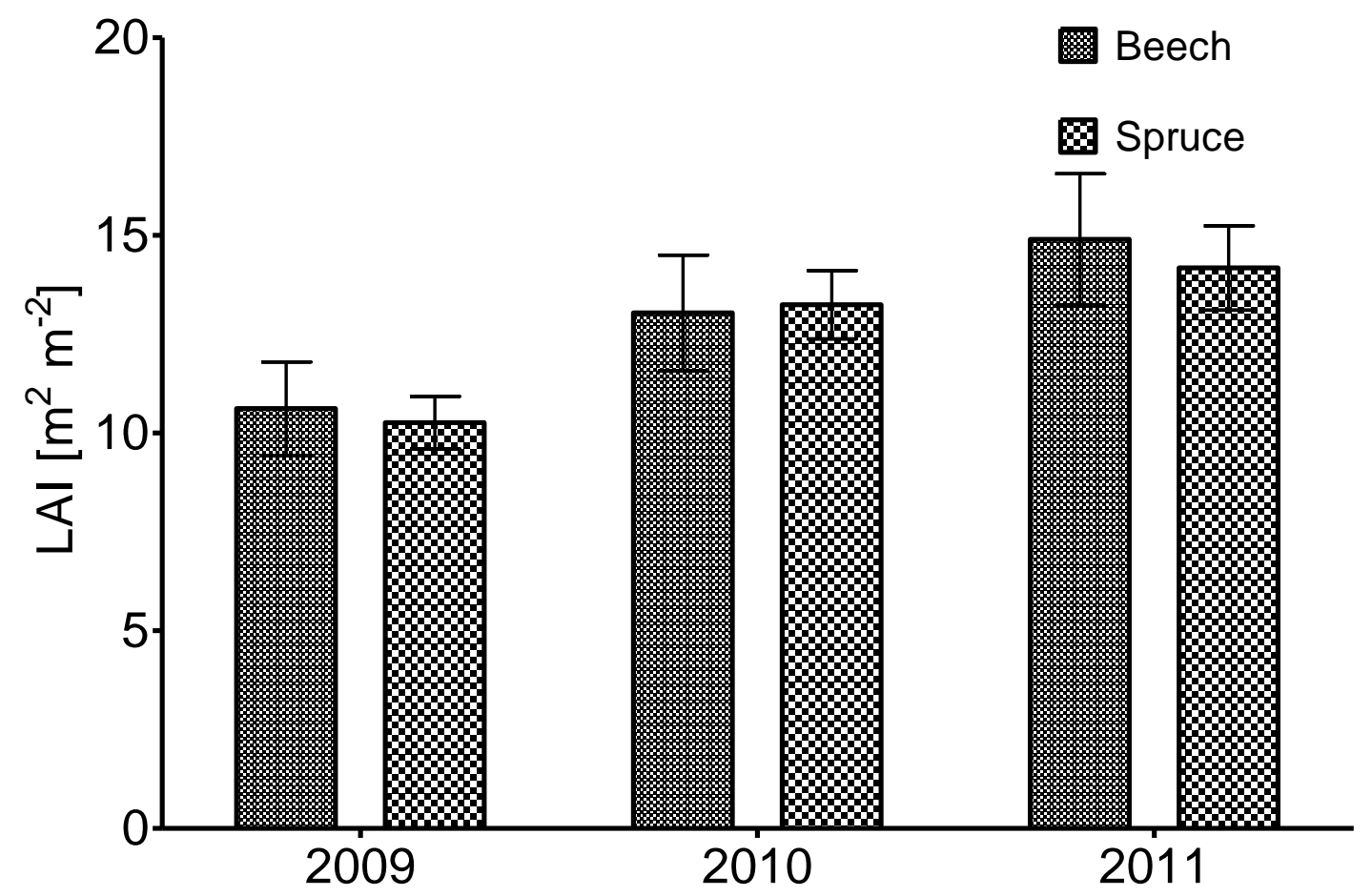

556 

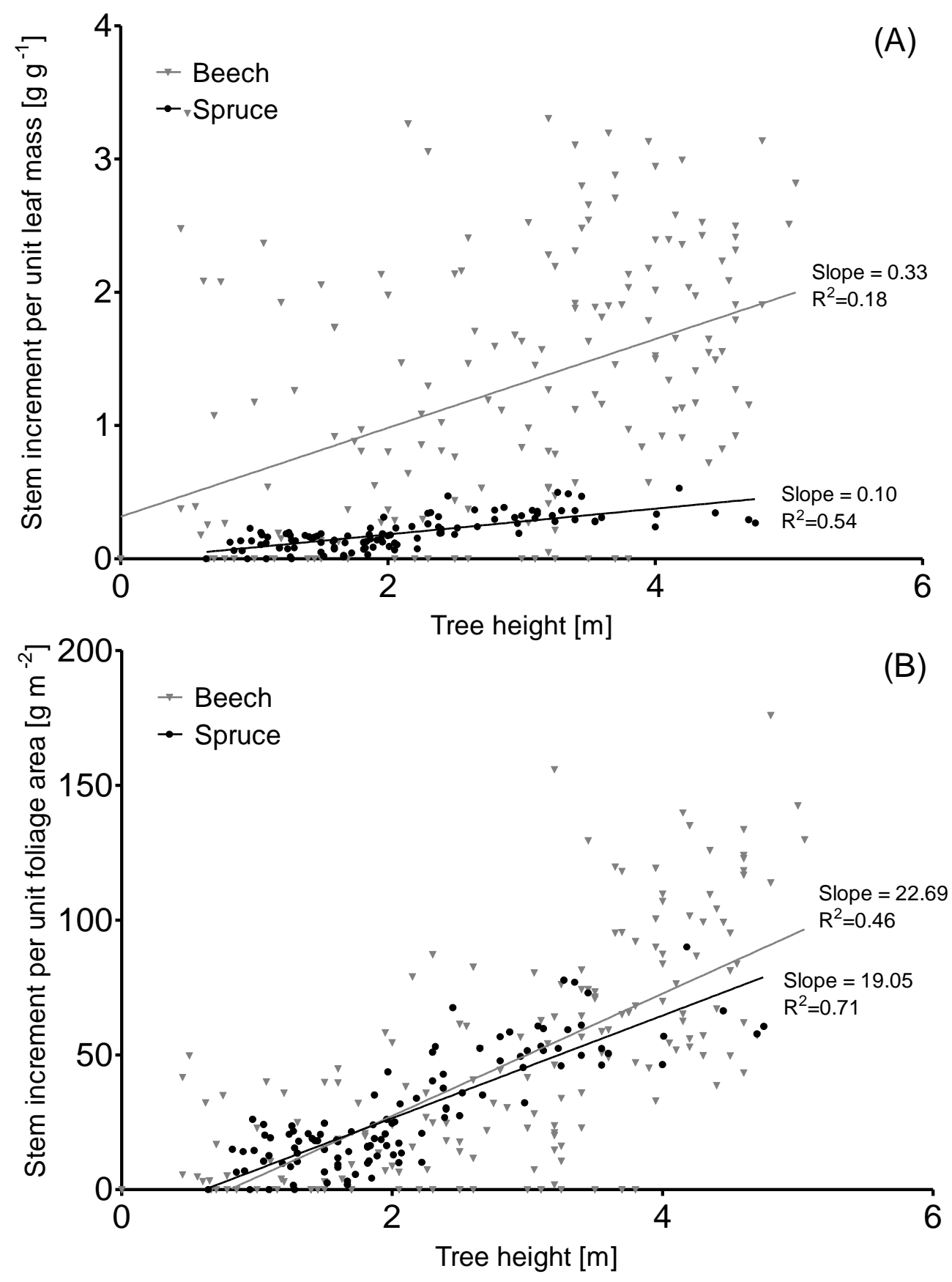
